\title{
PREVENÇÃO DA TUBERCULOSE EM GESTANTES NOS SERVIÇOS DE SAÚdE DA CAPITAL DE SÃo PAULO
}

\author{
Terezinha Joana Mei Garcia *
}

\section{NOTA PREVIA}

GARCIA, T.J.M. Prevenção da tuberculose em gestantes nos Serviços de Saúde da Capital de São Paulo. Nota prévia. Rev. Esc. Enf. USP, São Paulo, 14 (3): 355, 1980. assunto.

O autor proposse a estudar a prevenção da tuberculose em gestantes pela importância do

Os objetivos do estudo são:

- verificar se o teste tuberculínico (PPD-RT 23UT) é utilizado para se determinar a presença de tuberculose-infeç̧ão em gestantes nos Serviços de Saude da Capital de Sáo Paulo;

- verificar os procedimentos utilizados para a prevenção de tuberculose-doença em gestantes, nos Serviços de Saude da Capital de São Paulo.

$O$ instrumento de coleta de dados é um formulário semi-estruturado com perguntas sobre os procedimentos que estão sendo utilizados para prevenir a tuberculose-doença em gestantes.

O formulário é preenchido pelo profissional responsável pela unidade de atendimento prénatal, estando presente o pesquisador para esclarecimentos de possíveis dúvidas.

A pesquisa encontra-se em fase de coleta de dados.

GARCIA, T. J.M. Prevention of tuberculosis in pregnant women at the health services of São Paulo city. Previous note. Rev. Esc. Enf. USP, São Paulo, 14 (3): 335, 1980.

The author proposes to study the prevention of tuberculosis in pregnant women because of the importance of the subject.

The objectives are to find out:

1. If the tuberculine test (PPD - RT 23 UT) is used to determine the presence of tuberculose infection in pregnant women:

2. which procedures are used to prevent tuberculosis disease in such women.

The instrument for collecting data is a semi - structured questionnaire with questions about the procedures used for prevention of tuberculosis.

The questionnaire is filled by the professional responsible for the prenatal clinic.

The resercher will be present in order to clarify any possible doubts.

The study is the data collection phase.

- Docente da disciplina Enfermagem Obstétrica do Departamento de Enfermagem da Escola Paulista de Medicina. 